\title{
Using swine farming wastewater for Signal grass cultivation
}

\section{Uso da água residuária da suinocultura no cultivo do capim- Braquiária}

\author{
Bruno Grossi Costa Homem'; Valdir Botega Tavares²; \\ Onofre Barroca de Almeida Neto ${ }^{3}$; Marisa Senra Condé ${ }^{4}$; Igor Machado Ferreira ${ }^{5}$; \\ Mateus Diniz Silva ${ }^{6}$; Márcio André Stefanelli Lara ${ }^{7 *}$
}

\begin{abstract}
The objective of this study was to evaluate forage production and root accumulation in Brachiaria decumbens cv. Basilisk with swine wastewater as a fertilizer. The experiment was conducted into a greenhouse in Federal Institute of Education, Science and Technology of Southeast of Minas Gerais, Rio Pomba Campus. Pots with $6 \mathrm{dm}^{-3}$ volumes were used as experimental units. Were used a randomized block design with four replications. Were studied four swine waste doses $\left(0,225,450\right.$ and $\left.675 \mathrm{~mL} \mathrm{pot}^{-1}\right)$ over four regrowth cycles. The dry matter production of the aerial part, forage accumulation rate, crude protein and dry matter production of roots increased with the highest swine waste doses being around $670,742,160$ and $465 \%$ respectively from lower to higher dose. There was interaction between swine waste and regrowth cycles for plant height and tillering, and in all regrowth cycles responded positively with increasing swine waste doses. Applying swine waste on pastures is therefore a viable alternative to increase productivity of $B$. decumbens $\mathrm{cv}$. Basilisk, it recommends the use of swine waste corresponding to the dose of $675 \mathrm{~mL} \mathrm{pot}^{-1}$ to maintenance pastures.
\end{abstract}

Key words: Brachiaria. Effluents. Fertigation. Forage yield.

\section{Resumo}

Objetivou-se com este trabalho avaliar a produção de forragem e acúmulo de raízes em Brachiaria decumbens cv. Basilisk com o uso da água residuária de suínos como fertilizante. O experimento foi conduzido em casa de vegetação no Instituto Federal de Educação, Ciência e Tecnologia do Sudeste de Minas Gerais, Campus Rio Pomba. Vasos com volume de $6 \mathrm{dm}^{-3}$ foram utilizados como unidades experimentais, utilizou-se o delineamento em blocos casualizados com quatro repetições. Foram estudadas quatro doses de água residuária $\left(0,225,450\right.$ e $675 \mathrm{~mL}$ vaso $\left.{ }^{-1}\right)$ durante quatro ciclos de rebrotação. A produção de matéria seca da parte aérea, a taxa de acúmulo de forragem, a proteína bruta e a produção de matéria seca de raízes aumentaram com as doses de água residuária, com aumentos de cerca de 670, 742, 160 e 465\% respectivamente da menor para a maior dose. Houve interação entre doses

\footnotetext{
${ }^{1}$ Discente do Curso de Doutorado do Programa de Pós-Graduação em Zootecnia, Dept ${ }^{\circ}$ de Zootecnia, Universidade Federal de Lavras, UFLA, Lavras, MG, Brasil. E-mail: zoogrossi@gmail.com

2 Prof., Dept ${ }^{\circ}$ de Zootecnia, Instituto Federal de Educação, Ciência e Tecnologia do Sudeste de Minas Gerais, IF Sudeste MG, Campus Rio Pomba, Rio Pomba, MG, Brasil. E-mail: valdir.botega@ifsudestemg.edu.br

3 Prof., Dept ${ }^{\circ}$ de Educação, IF Sudeste MG, Campus Rio Pomba, Rio Pomba, MG, Brasil. E-mail: onofre.neto@ifsudestemg.edu.br

${ }^{4}$ Zootecnista, IF Sudeste MG, Campus Rio Pomba, Rio Pomba, MG, Brasil. E-mail: marisa.senra@yahoo.com.br

5 Discente do Curso de Graduação em Zootecnia, UFLA, Lavras, MG, Brasil. E-mail: igorzootecnia@yahoo.com.br

${ }^{6}$ Discente do Curso de Graduação em Zootecnia, IF Sudeste MG, Campus Rio Pomba, Rio Pomba, MG, Brasil. E-mail: mateusdinizsilva@hotmail.com

${ }^{7}$ Prof., Dept ${ }^{\circ}$ de Zootecnia, Universidade Federal de Lavras, UFLA, Lavras, MG, Brasil. E-mail: marciolara@dzo.ufla.br

* Author for correspondence
} 
de água residuária e ciclos de rebrotação para as variáveis, altura das plantas e densidade populacional de perfilhos, sendo que em todos os ciclos de rebrotação, responderam positivamente com o aumento das doses de água residuária. A aplicação de água residuária suína é uma alternativa viável para aumento da produtividade da $B$. decumbens $\mathrm{cv}$. Basilisk, recomenda-se o uso de água residuária correspondente à dose de $675 \mathrm{~mL}$ vaso $^{-1}$ na manutenção das pastagens.

Palavras-chave: Brachiaria. Efluentes. Fertirrigação. Produção de forragem.

\section{Introduction}

The adoption of new technologies and investments for animal production on Brazilian pastures has been low (DIAS-FILHO, 2011). One of the largest constraints to higher productivity is lack of nutrient replenishment, resulting in the depletion of natural soil fertility (KESSLER et al., 2013).

Mineral fertilizers, especially those containing nitrogen, increase both forage productivity and nutritional value (SOLLENBERGER, 2008). However, nitrogen use is often limited by its high cost, with the average price per ton having increased by more than $500 \%$ within the last 20 years in Brazil (ANDA, 2015). Swine farm effluent, or swine wastewater, offers a promising alternative for pasture fertilization at lower production costs (MONDARDO et al., 2011).

The use of swine wastewater on Brazilian pastures is increasingly common, both as a source of macro and micronutrients (ASSMANN et al., 2009) and because it provides a viable ecological destination for swine farming effluent (FONSECA et al., 2007).

Swine wastewater increases the nutritional value and forage yield of grass pasture systems (FONSECA, et al., 2007; SCHEFFER-BASSO et al., 2008; VIELMO et al., 2011; KESSLER et al., 2013). However, its influence on forage growth dynamics and root development remains unclear, due to variations in the composition and dosage of the applied wastewater.

The aim of this work was to evaluate how the use of swine wastewater as a fertilizer impacts forage production and root mass of Brachiaria decumbens (Stapf.) cv. Basilisk.

\section{Material and Methods}

The experiment was conducted with $B$. decumbens (Stapf.) cv. Basilisk grown in pots in a greenhouse between January 8 and April 2, 2013, within the Meristem and Plant Propagation Sector at the Instituto Federal de Educação, Ciência e Tecnologia do Sudeste de Minas Gerais (Federal Institute of Education, Science and Technology of Southeastern Minas Gerais), Rio Pomba Campus (IFET-RP), Rio Pomba, MG, Brazil (2114'30.78"S, $\left.43^{\circ} 09^{\prime} 39.31^{\prime \prime} \mathrm{W}\right)$. A randomized block design with four treatments (dosages of swine wastewater: 0 , 225,450 and $675 \mathrm{~mL} \mathrm{pot}^{-1}$ ) and four replicates was used, for a total of 16 experimental units (pots).

One red-yellow dystrophic latosol was used, containing $490 \mathrm{~g} \mathrm{~kg}^{-1}$ of clay. The soil was collected on September 10, 2012, from the 0-20 cm layer of a 15-year-old pastureland cultivated with Brachiaria brizantha cv. Marandu that had received no fertilizer or other soil improvers in the previous five years. Soil lumps were broken and passed through a 5-mm sieve. A soil sample was passed through a 2-mm sieve for chemical analysis (EMBRAPA, 1997), which yielded a $\mathrm{pH} \mathrm{H}_{2} \mathrm{O}$ of $5.10 ; 1.1 \mathrm{~g} \mathrm{~L}^{-1}$ of organic matter (OM); $1.2 \mathrm{mg} \mathrm{L}^{-1} \mathrm{P}$ (Mehlich 1); $5 \mathrm{mg} \mathrm{L}^{-1} \mathrm{~K} ; 0.1 \mathrm{cmol}_{\mathrm{c}} \mathrm{L}^{-1} \mathrm{Ca}^{2+} ; 0.0 \mathrm{cmol}_{\mathrm{c}} \mathrm{L}^{-1} \mathrm{Mg}^{2+}$; $2.31 \mathrm{cmol}_{\mathrm{c}} \mathrm{L}^{-1} \mathrm{Al}^{3+}+\mathrm{H}^{+}$; a Sum of Bases (SB) of $0.11 \mathrm{cmol}_{c} \mathrm{~L}^{-1} ; 0.4 \mathrm{cmol}_{\mathrm{c}} \mathrm{L}^{-1} \mathrm{Al}^{3+} ; 0.51 \mathrm{cmol}_{\mathrm{c}} \mathrm{L}^{-1}$ effective cation-exchange capacity (ECEC), and $5.0 \%$ base saturation. Following chemical analysis, $85 \%$ CCE dolomite lime was mixed into the soil at a rate of $0.8 \mathrm{~g} \mathrm{~L}^{-1}$, and the soil was incubated for 60 days prior to use.

On November 24, the soil was homogenized and placed in 6-L pots without drainage holes (pot area 
at top: $0.045 \mathrm{~m}^{2}$; diameter, $24 \mathrm{~cm}$; height, $20 \mathrm{~cm}$ ), which were filled to $1 \mathrm{~cm}$ from the top with $6 \mathrm{~kg}$ of soil. We then applied triple superphosphate and potassium chloride to the soil surface which $75 \mathrm{mg}$ $\mathrm{dm}^{-3}$ de $\mathrm{P}_{2} \mathrm{O}_{5}$ (with $41 \% \mathrm{P}_{2} \mathrm{O}_{5}$, w/w) and $30 \mathrm{mg} \mathrm{dm}^{-3}$ de $\mathrm{K}_{2} \mathrm{O}$ (with $58 \% \mathrm{~K}_{2} \mathrm{O}$, w/w).

On November 25, $0.5 \mathrm{~g}$ ( $50 \%$ of cultural value) of $B$. decumbens cv. Basilisk seed was planted per pot. Periodic thinning was initiated after twenty days of seedling emergence and performed according to a visual pattern of seedling weight and vigor, until four plants per pot were obtained. Water content was kept at $70 \%$ of the maximum water retention capacity (0.540 $\mathrm{L} \mathrm{kg}^{-1}$ soil) (EMBRAPA, 1997).
The pots were weighed two times per day, and the quantity of water to be added was determined by the difference between initial pot weight and weight at the moment of assessment.

Swine wastewater (SW) was collected from a private property in the Rio Pomba municipality, state of Minas Gerais, Brazil. The collecting system included three series of decantation ponds. Solid manure was filtered prior to entering the first pond. The SW used in experiments was collected from the second pond and stored in 50-liter containers. On collection day, a sample was separated for physical, chemical and biochemical characterization (Table 1) according to APHA/AWWA/WEF (2005).

Table 1. Physical and biochemical analysis of swine wastewater.

\begin{tabular}{|c|c|c|c|c|c|c|c|}
\hline$\dagger \mathrm{pH}$ & $\mathrm{N}$ & Water hardness & $\mathrm{CaCO}_{3}$ & $\mathrm{MgCO}_{3}$ & COD & EC & SS \\
\hline $\mathrm{H}_{2} \mathrm{O}$ & \multicolumn{5}{|c|}{ - } & ds.m ${ }^{-1}$ & $\mathrm{ml} \mathrm{L}^{-1}$ \\
\hline 8,16 & 2.416 & 985 & 214 & 378 & 44.000 & 17.56 & 2 \\
\hline $\mathrm{Na}^{+}$ & $\mathrm{K}^{+}$ & $\mathrm{P}$ & TS & FS & VS & TSS & TDS \\
\hline \multicolumn{8}{|c|}{ 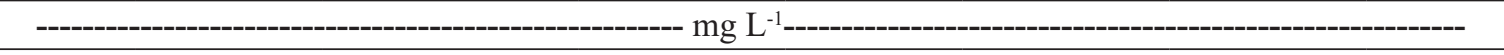 } \\
\hline 432 & 1.580 & 48 & 5.085 & 3.500 & 2.350 & 90 & 5.760 \\
\hline
\end{tabular}

$\uparrow \mathrm{pH}=$ Hydrogen Potential; $\mathrm{N}=$ Total Nitrogen; $\mathrm{CaCO}_{3}=$ Calcium Carbonate $\mathrm{MgCO}_{3}=$ Magnesium Carbonate $\mathrm{COD}=\mathrm{Chemical}$ Oxygen Demand; EC = electric conductivity; $\mathrm{SS}=$ Settleable Solids; $\mathrm{Na}^{+}=$Sodium; $\mathrm{K}^{+}=$Potassium; $\mathrm{P}=\mathrm{Total}$ Phosphorus; $\mathrm{TS}=$ Total Solids; FS = Fixed Solids; VS = Volatile Solids; TSS $=$ Total Suspended Solids; TDS $=$ Total Dissolved Solids.

Swine wastewater doses were defined after its characterization, assuming potassium as the limiting chemical component. The table for fertilization and maintenance of pastures at a medium technological level was used (RIBEIRO et al., 1999). Low (20 mg $\left.\mathrm{dm}^{-3}\right)$, medium (40 $\left.\mathrm{mg} \mathrm{dm}^{-3}\right)$ and high doses $(60 \mathrm{mg}$ $\mathrm{dm}^{-3}$ ) of potassium were provided to the soil via SW, equivalent to 225,450 and $675 \mathrm{~mL} \mathrm{pot}^{-1}$ during the culture cycle (Table 2).

Table 2. Nutrient application according to swine wastewater (SW) dosage.

\begin{tabular}{|c|c|c|c|c|c|c|}
\hline \multirow{2}{*}{$\begin{array}{l}\text { SW dosage } \\
\left(\mathrm{mL} \mathrm{pot}^{-1}\right)\end{array}$} & $\dagger \mathrm{N}$ & $\mathrm{P}$ & $\mathrm{K}^{+}$ & $\mathrm{Ca}^{2+}$ & $\mathrm{Mg}^{2+}$ & $\mathrm{Na}^{+}$ \\
\hline & \multicolumn{6}{|c|}{ - } \\
\hline 225 & 544 & 10,8 & 355 & 19,3 & 24,7 & 97,2 \\
\hline 450 & 1088 & 21,6 & 711 & 38,7 & 49,4 & 194,4 \\
\hline 675 & 1632 & 32,4 & 1065 & 57,9 & 74,1 & 291,6 \\
\hline
\end{tabular}

$\uparrow \mathrm{N}=$ Total nitrogen; $\mathrm{P}=$ Phosphorus; $\mathrm{K}^{+}=$Potassium; $\mathrm{Ca}^{2+}=$ Calcium; $\mathrm{Mg}^{2+}=$ Magnesium e $\mathrm{Na}^{+}=$Sodium. 
The nutrient supplementation provided by SW was estimated based on SW total nutrient concentration and volumes applied per cycle (Table 2). This estimate considered only the total levels of each nutrient, disregarding which forms they assumed in the effluent.

$B$. decumbens growth was studied during four regrowth cycles. Plants were harvested five centimeters above ground at fixed intervals of 25 days, starting 30 days after the last thinning. Each SW dose was divided into four applications, one of which was applied after each of the four harvests. The first application was on January 9, the second on February 5, the third on March 5 and the fourth on April 2, 2013.

Maximum and minimum temperatures at the greenhouse, as well as relative air humidity, were measured daily using a Thermo-Hygrometer (model 7663.02.0.00, Incoterm). Averages for regrowth cycles 1, 2, 3 and 4 were: maximum temperature, $27.27{ }^{\circ} \mathrm{C}, 29.15{ }^{\circ} \mathrm{C}, 27.16{ }^{\circ} \mathrm{C}$, and $24.82{ }^{\circ} \mathrm{C}$; minimum temperature, $18.49{ }^{\circ} \mathrm{C}, 18.68{ }^{\circ} \mathrm{C}, 18.41$ ${ }^{\circ} \mathrm{C}$, and $16.04{ }^{\circ} \mathrm{C}$; and relative air humidity, $82.45 \%$, $76.40 \%, 84.99 \%$, and $83.15 \%$, respectively.

Prior to harvest, average plant height was measured using a ruler and an acetate film placed over the plants (in the pot), and tiller density (TD) was quantified for each pot. Harvested grass was placed into plastic bags, tagged and weighed fresh. Samples were then divided in leaf and stem, and dried in paper bags in a forced-draft oven at $65^{\circ} \mathrm{C}$ for $72 \mathrm{~h}$. Dried samples were ground in a Wileytype grinder with a 1-mm sieve and analyzed for dry matter (DM; $105^{\circ} \mathrm{C}$ for $16 \mathrm{~h}$ ) and crude protein (CP) contents (AOAC, 2005). These data were used to quantify forage, leaf and stem dry matter (DM) production, as well as the daily rate of forage accumulation (FAR), calculated by dividing forage DM production by regrowth period (in days).

At the end of the experimental period, the roots were removed from the pots, sieved, washed and dried in paper bags in a forced-draft oven at $65^{\circ} \mathrm{C}$ for $72 \mathrm{~h}$. Dried samples were ground in a Wileytype grinder with a 1-mm sieve and analyzed for dry matter content (DM; $105^{\circ} \mathrm{C}$ for $\left.16 \mathrm{~h}\right)$ to quantify root DM production (MARTUSCELLO et al., 2005).

Variance analysis of production and morphology data focused on the effects of dosage, regrowth cycle and interactions between them. Statistical analysis was performed using R statistical software, version 3.0.3 (FERREIRA et al., 2011). Wherever possible, results are shown as regressions against SW dosage. The effects of SW dosage, regrowth cycles and respective interactions were considered fixed effects. Blocks and respective interactions with other sources of variation were considered random effects (LITTELL et al., 2006). Equations were selected based on the coefficient of determination $\left(\mathrm{R}^{2}\right)$, considered a $10 \%$ probability, according to the $\mathrm{F}$ test, and took the form:

$$
\mathrm{Yijk}=\mu+\mathrm{Bi}+\mathrm{Dj}+\gamma \mathrm{ij}+\mathrm{Ck}+(\mathrm{DC}) \mathrm{jk}+\varepsilon \mathrm{ijk}
$$

where Yijk = observed value of the ith block of the jth SW dose of the kth resprouting cycle; $\mu$ $=$ general average; $\mathrm{Bi}=$ random effect associated with the ith block, $\mathrm{i}=1, \ldots, 4 ; \mathrm{Dj}=$ fixed effect associated with the jth SW dose, $\mathrm{j}=1, \ldots, 4$; rij $=$ random effect associated with the ith block of the jth SW dose, assuming $\gamma \mathrm{ij} \sim \mathrm{N}(0, \mathrm{I} \sigma 2 \gamma), \mathrm{I} \sigma 2 \gamma$ being the variance and covariance identity matrix, and residues assumed independent; $\mathrm{Ck}=$ fixed effect associated with the kth regrowth cycle, $\mathrm{k}=1, \ldots$, 4; (DC)jk = interaction effect between the jth SW dose and the kth regrowth cycle; cijk = random error associated with the ith block of the jth SW dose in the kth regrowth cycle, assuming $\varepsilon i j \mathrm{k} \sim \mathrm{N}(0, \mathrm{I} \sigma 2 \varepsilon)$, $\mathrm{I} \sigma 2 \varepsilon$ being the variance and covariance matrix, and errors considered independent.

\section{Results and Discussion}

Only SW dosage affected production of DM (P $=0.004)$, FAR $(P=0.004)$ and $\mathrm{CP}(\mathrm{P}=0.001) . \mathrm{DM}$ increased from 1.9 to $13.0 \mathrm{~g} \mathrm{DM} \mathrm{pot}^{-1}$ with maximum SW fertilization (675 mL SW pot ${ }^{-1}$ ) (Table 3). 
Mineral uptake is essential for forage production, as it influences the morphological characteristics of the plant community. Nitrogen increases the leaf appearance rate and leaf elongation rate, resulting in higher biomass production (GIMENES et al.,
2011). SW improved the production of forage DM, confirming its potential as a source of nutrients for pasture (FONSECA, et al., 2007; SCHEFFERBASSO et al., 2008; VIELMO et al., 2011; KESSLER et al., 2013).

Table 3. B. decumbens cv. Basilisk dry matter (DM) production, forage accumulation rate (FAR), root DM production and crude protein $(\mathrm{CP})$ content as affected by fertilization with swine wastewater.

\begin{tabular}{|c|c|c|c|c|c|c|c|c|}
\hline \multirow{2}{*}{ Variables } & \multicolumn{4}{|c|}{ SW doses } & \multirow{2}{*}{$\begin{array}{l}\text { General } \\
\text { Average }\end{array}$} & \multirow{2}{*}{ SEM } & \multicolumn{2}{|c|}{ P-Value } \\
\hline & 0 & 225 & 450 & 675 & & & $\mathrm{~L}$ & Q \\
\hline$\dagger$ DM yield $\left(\right.$ g pot $\left.^{-1}\right)$ & 1.75 & 8.10 & 11.30 & 12.86 & 8.50 & 0.050 & $<0.0001$ & 0.0240 \\
\hline FAR $\left(\right.$ g pot $^{-1}$ day $\left.^{-1}\right)$ & 0.06 & 0.29 & 0.40 & 0.45 & 0.30 & 0.005 & $<0.0001$ & 0.0240 \\
\hline Root yield ( $\left.\mathrm{g} \mathrm{pot}^{-1}\right)$ & 7.84 & 22.48 & 29.58 & 36.51 & 24.10 & 0.610 & 0.0020 & 0.4489 \\
\hline $\mathrm{CP}(\%)$ & 6.73 & 8.36 & 9.24 & 10.81 & 8.78 & 0.022 & $<0.0001$ & 0.9360 \\
\hline
\end{tabular}

$\dagger \mathrm{DM}=$ Dry matter; FAR $=$ Forage accumulation rate; $\mathrm{CP}=$ Crude protein; $\mathrm{SEM}=$ Standard error of the mean. $\mathrm{DM}$ yield $=1.8255$ $+0.0322 \mathrm{SW}-0.00002 \mathrm{SW} 2, \mathrm{R}^{2}=0.99 ; \mathrm{FAR}=0.065+0.0011 \mathrm{SW}-0.000001 \mathrm{SW} 2, \mathrm{R}^{2}=0.99 ;$ Root yield $=10.136+0.0414 \mathrm{SW}$, $\mathrm{R}^{2}=0.96 ; \mathrm{CP}=6.817+0.0058 \mathrm{SW}, \mathrm{R}^{2}=0.98$.

SW influenced FAR, which varied from 0.07 to $0.56 \mathrm{~g}$ of $\mathrm{DM}$ pot $^{-1} \mathrm{day}^{-1}$, with the maximum FAR occurring in the $675 \mathrm{~mL} \mathrm{SW} \mathrm{pot}^{-1}$ treatment (Table 3), an increase of $742 \%$ compared to the zero dose $\left(0.07 \mathrm{~g} \mathrm{DM}_{\text {pot }}{ }^{-1}\right.$ day $\left.^{-1}\right)$. Vielmo et al. (2011) obtained similar FARs when evaluating the response of Tifton 85 to SW fertilization. The authors reported a FAR of $0.68 \mathrm{~g} \mathrm{DM}$ day $^{-1}$ when the dose was adjusted to a pot area of $720 \mathrm{~mL}^{-1}$ 1. Thus, the changes in plant growth caused by fertilization create the necessity of adjustments in defoliation management to maintain forage harvest efficiency (FONSECA et al., 2007).

Forage CP content increased linearly with SW dosage (Table 3), with means varying from $6.73 \%$ for $0 \mathrm{~mL} \mathrm{pot}^{-1}$ to $10.8 \%$ for the $675 \mathrm{~mL} \mathrm{pot}^{-}$ 1 treatment. The best indices were obtained with SW quantities of 450 and $675 \mathrm{~mL} \mathrm{pot}^{-1}$. SchefferBasso et al. (2008) showed that CP content responds positively to increased swine slurry dosage, reporting a $26 \%$ increase in $\mathrm{CP}$ content of Tifton- 85 relative to the control when $180 \mathrm{~m}^{-3}$ $\mathrm{ha}^{-1}$ of swine liquid waste (SLW) was applied (equivalent to a dose of $846 \mathrm{~mL} \mathrm{pot}^{-1}$ ). On the other hand, Medeiros et al. (2007) observed that $180 \mathrm{~m}^{-3}$ $\mathrm{ha}^{-1}$ of SLW produced an average CP content of $9.8 \%$ in marandu grass. Assmann et al. (2009) and Matos et al. (2013) reported CP content increases in proportion to the level of wastewater nitrogen, highlighting the importance of nitrogen content of SW for its positive effect on dry matter production and on nitrogen content of tropical grass tissues.

Root mass was also influenced only by SW dosage $(\mathrm{P}=0.013)$, with a linear increase in root DM observed as SW dose was increased (Table 3). The nutrient supply interfere on growth and morphology of the roots (SARMENTO et al., 2008). Giacomini et al. (2005), Batista and Monteiro (2006), and Ferreira et al. (2013) reported similar results for Panicum maximum (Jacq.) cv. Tanzânia , Marandu, and Piatã grasses, respectively. All of those authors observed increases in root DM with higher doses of nitrogen fertilizer. Nutrient supply affects root growth and morphology, with longer roots occurring with low nitrogen supply, while higher nitrogen supply reduces root length but increases their number, resulting in an enhanced nutrient absorption rate. 
According to Santos Júnior et al. (2004), higher doses of nitrogen allow for a larger retention of photosynthesized material in leaves, the most important element of animal feeding. On the other hand, nitrogen deficits force leaves to export more photosynthetic compounds to the roots, thereby limiting leaf growth.

DM production in leaves and stems was affected by the interaction between SW dosage and regrowth cycle ( $\mathrm{P}<0.001$ and $\mathrm{P}<0.001$, respectively) and responded linearly to increased SW (Figure 1).
Differences in leaf DM were found for cycles 1,2 and $3(\mathrm{P}=0.058 ; \mathrm{P}<0.001$ and $\mathrm{P}=0.027$, respectively), whereas differences in stem $\mathrm{DM}$ were found only for cycles 2 and 3 ( $P<0.001$ and $\mathrm{P}=0.090$, respectively). These increases in leaf and stem mass were due to a higher availability of soil nutrients, especially $\mathrm{N}$, derived from mineralization of SW organic matter. Fagundes et al. (2006) reported similar results when assessing how the structural characteristics $B$. decumbens responded to $\mathrm{N}$ mineral dosage.

Figure 1. B. decumbens cv. Basilisk leaf and stem masses as functions of swine wastewater applied dosage.

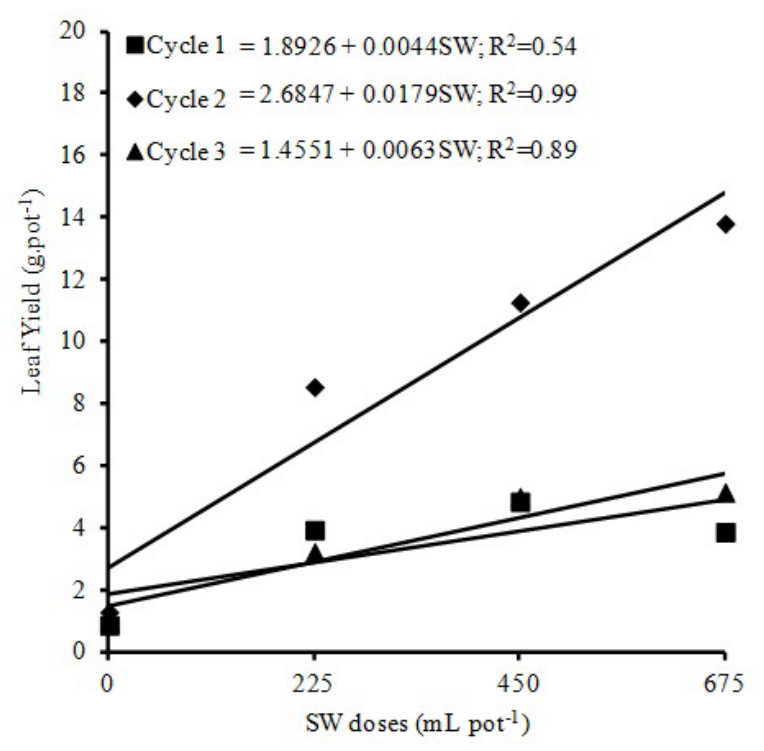

The average plant height was affected by the interaction between SW dosage and regrowth cycle $(\mathrm{P}<0.001)$. Mean plant height responded quadratically to increased $\mathrm{SW}$ dose in all regrowth cycles (Figure 2), varying from $10 \mathrm{~cm}$ in cycle 4, without SW application, to $67.5 \mathrm{~cm}$ in cycle 2, with the maximum SW dose. Plant height maxima were observed with the following doses: 470, 718.5, 682 and $550 \mathrm{~mL} \mathrm{SW} \mathrm{Pot}^{-1}$ for cuts 1, 2, 3 and 4, respectively. The observed canopy height response agrees with results by Scheffer-Basso et al. (2008) for Cynodon spp. cv. Tifton 85 using (non-treated) swine slurry. These authors observed an increase

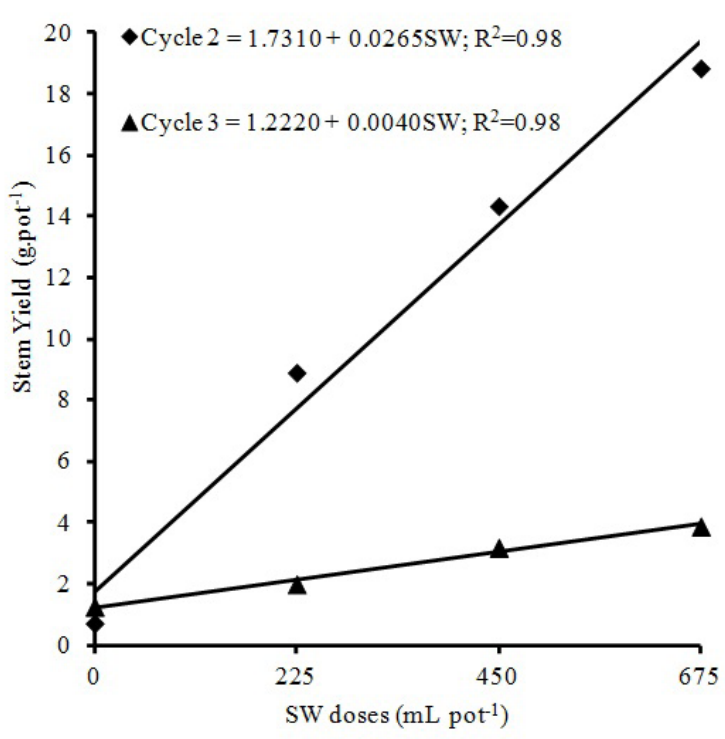

in the canopy height with increasing slurry doses. Araújo et al. (2011) reported an increase in canopy height with increasing doses of (non-treated) bovine liquid waste. A positive effect on Marandu grass canopy height was also observed by Santos et al. (2009) using mineral nitrogen fertilizers.

TD also responded quadratically to the increase in $\mathrm{SW}$ dose in all regrowth cycles $(\mathrm{P}=0.002)$, with tiller population per pot varying from 10 (in cycle 4 without SW application) to approximately 48 (in cycle 2 with the maximum SW dose) (Figure $3)$. There was a $480 \%$ difference in TD between 
the minimum and maximum $\mathrm{SW}$ treatments. Maximum TD was observed for the following SW doses: 561, 548, 522 and $424 \mathrm{~mL} \mathrm{SW} \mathrm{Pot}^{-1}$ for cycles 1, 2, 3 and 4, respectively. Plants fertilized with SW have advantages over those without an added supply of nutrients, especially nitrogen. The TD response to SW reported here correlates with results reported by Alexandrino et al. (2004) for Marandu grass, although those authors found a linear, rather than quadratic, increase of TD with increasing nitrogen dose. Those authors stated that the increase in DM is always larger with young tillers, which have a greater growth potential than older tillers.

Figure 2. B. decumbens cv. Basilisk height, measured in four regrowth cycles, as a function of swine wastewater applied dosage.

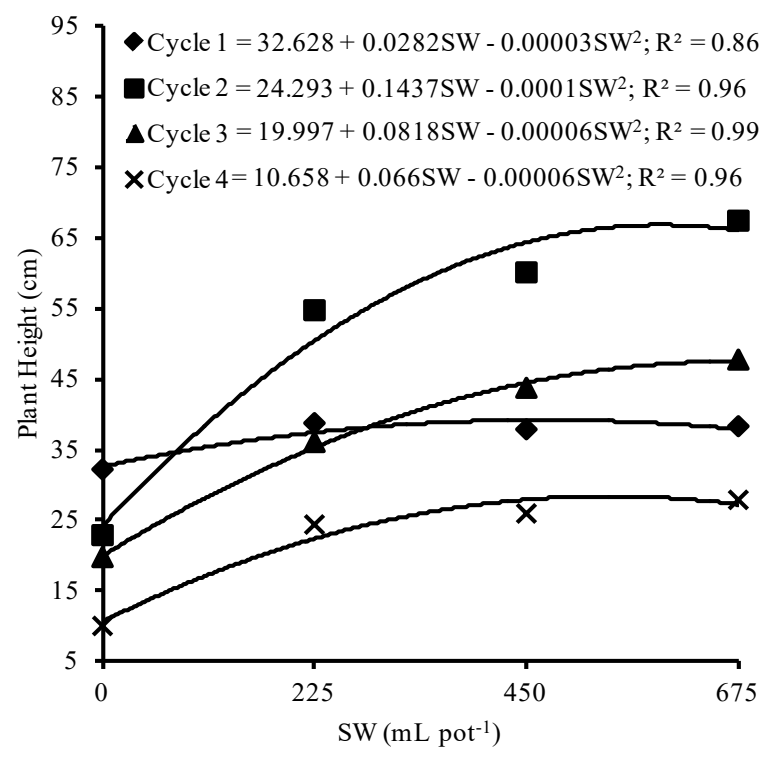

Figure 3. B. decumbens cv. Basilisk tiller population density, counted in four regrowth cycles, as a function of swine wastewater applied dosage.

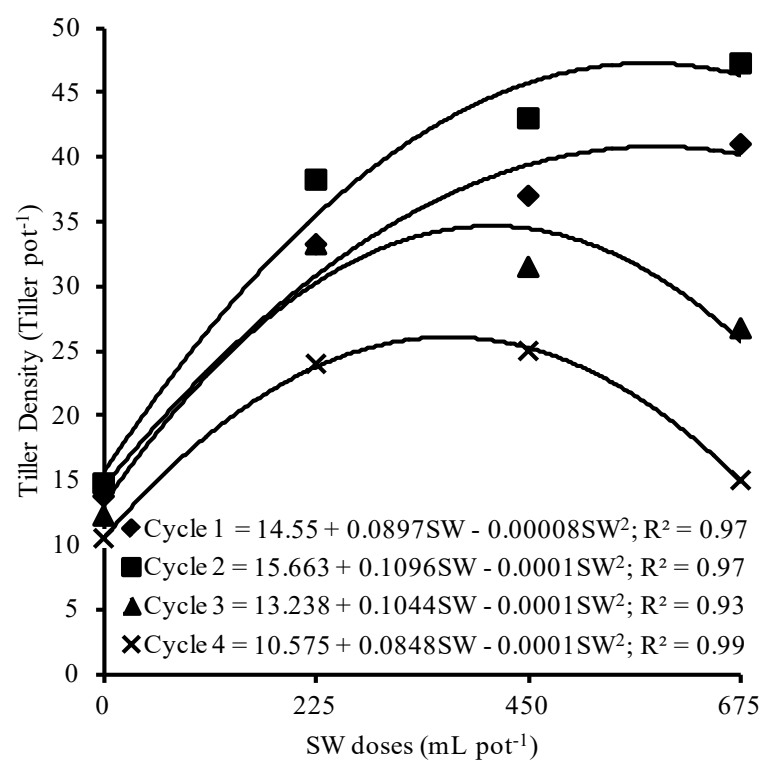




\section{Conclusion}

The use of swine wastewater is a viable method for increasing biomass production in $B$. decumbens cv. Basilisk. The experiment described here could not identify the best SW dose, since the largest applied dose $\left(675 \mathrm{~mL} \mathrm{pot}^{-1}\right)$ gave the greatest response. Additional increases in biomass production in the aerial parts and roots might be achieved with even higher doses of swine wastewater.

\section{Acknowledgments}

To IFET (Instituto Federal de Educação, Ciência e Tecnologia do Sudeste de Minas Gerais, Câmpus Rio Pomba) for the provision of a graduate scholarship and research funds for this project.

To FAPEMIG (Fundação de Amparo à Pesquisa do Estado de Minas Gerais), for support the publication.

\section{References}

ALEXANDRINO, E.; NASCIMENTO JÚNIOR, D.; MOSQUIM, P. R.; REGAZZI, A. J.; ROCHA, F. C. Características morfogênicas e estruturais na rebrotação da Brachiaria brizantha cv. Marandu submetida a três toses de nitrogênio. Revista Brasileira de Zootecnia, Viçosa, MG, v. 33, n. 6, p. 1372-1379, 2004.

ASSOCIATION OF OFFICIAL ANALYTICAL CHEMISTS - AOAC International. Official methods of analysis of AOAC International. $18^{\text {th }}$ ed. Gaithersburg: AOAC International, 2005.

ASSOCIAÇÃO NACIONAL PARA DIFUSÃO DE ADUBOS - ANDA. Anuário estatístico do setor de fertilizantes do ano de 2014. São Paulo: Associação Nacional para difusão de adubos, ANDA. 2015. Disponível em: $\quad<$ http://www.anda.org.br/index. php?mpg=06.01.00\&ver=por $>$. Acesso em: 16 jul. 2015.

AMERICAN PUBLIC HEALTH ASSOCIATION APHA; AMERICAN WATER WORKS ASSOCIATION - AWWA; WATER ENVIRONMENT FEDERATION WEF. Standard methods for the examination of water and wastewater. $21^{\text {th }}$ ed. Washington: APHA/AWWA/WEF, 2005. $1268 \mathrm{p}$.
ARAÚJO, A. S.; SANTOS, A. C.; SILVA NETO, S. P.; SANTOS, P. M. Produtividade do capim-marandu e alterações químicas do solo submetido a doses de dejetos líquidos de bovinos. Revista de Ciências Agrárias, Recife, v. 54, n. 3, p. 235-246, 2011.

ASSMANN, J. M.; BRAIDA, J. A.; CASSOL, L. C. MAGIERO, E. C.; MANTELI, C.; GRIZ, E. Produção de matéria seca de forragem e acúmulo de nutrientes em pastagem anual de inverno tratada com esterco líquido de suínos. Ciência Rural, Santa Maria, v. 39, n. 8, p. 24082416, 2009.

BATISTA, K.; MONTEIRO, F. A. Sistema radicular do capim-Marandu, considerando as combinações de doses de $\mathrm{N}$ e de enxofre. Revista Brasileira de Ciência do Solo, Viçosa, MG, v. 30, n. 1, p. 821-828, 2006.

DIAS-FILHO, M. B. Os desafios da produção animal em pastagens na fronteira agrícola brasileira. Revista Brasileira de Zootecnia, Viçosa, MG, v. 40, p. 243-252, 2011. Suplemento Especial.

EMPRESA BRASILEIRA DE PESQUISA AGROPECUÁRIA - EMBRAPA. Manual de métodos de análise de solo. 2. ed. Rio de Janeiro: Centro Nacional de Pesquisa de Solos, 1997. 212 p.

FAGUNDES, J. L.; FONSECA, D. M.; MORAIS, R. V.; MISTURA, C.; TEIXEIRA VITOR, C. M.; GOMIDE, J. A.; NASCIMENTO JUNIOR, D.; SANTOS, M. E. R.; LAMBERTUCCI, D. M. Avaliação das características estruturais do capim-braquiária em pastagens adubadas com nitrogênio nas quatro estações do ano. Revista Brasileira de Zootecnia, Viçosa, MG, v. 35, n. 1, p. 30-37, 2006.

FERREIRA, E. B.; CAVALCANTI, P. P.; NOGUEIRA, D. A. Experimental designs: um pacote R para análise de experimentos. Revista da Estatística da UFOP, Ouro Preto, v. 1, n. 1, p. 1-9, 2011.

FERREIRA, R. S.; SILVA JÚNIOR, C. A.; TEODORO, P. E.; SILVA, P. P.; ARIMA, G. M.; CAPPI, N.; TORRES, F. E. Effect of different doses of swuine biofertilizer in the development and production of cultivars of Brachiaria brizantha. Journal of Agronomy, Nova York, v. 12, n. 1, p. 53-58, 2013.

FONSECA, A. F. da; MELFI, A. J.; MONTEIRO, F. A.; MONTES, C. R.; ALMEIDA, V. V.; HERPIN, U. Treated sewage effluent as a source of water and nitrogen for Tifton 85 bermudagrass. Agricultural Water Management, Melbourne, v. 87, n. 3, p. 328-336, 2007.

GIACOMINI, A. A.; MATTOS, W. T.; MATTOS, H. B.; WERNER, J. C.; CUNHA, E. A.; CARVALHO, D. D. Crescimento de raízes dos capins Aruana e Tanzânia submetidos a duas doses de nitrogênio. Revista Brasileira Zootecnia, Viçosa, MG, v. 34, n. 4, p. 1109-1120, 2005. 
GIMENES, F. M. de A.; SILVA, S. C. da; FIALHO, C. A.; GOMES, M. B.; BERNDT, A.; GERDES, L.; COLOZZA, M. T. Ganho de peso e produtividade animal em capim-marandu sob pastejo rotativo e adubação nitrogenada. Pesquisa Agropecuária Brasileira, Brasília, v. 46, n. 7, p. 751-759, 2011.

KESSLER, N. C. H.; SAMPAIO, S. C.; SORACE, M.; PRADO, N. V.; PALMA, D.; CUNHA, E.; ANDRADE, L. $\mathrm{H}$. Swine wastewater associated with mineral fertilization in blackoat (Avena sativa) cultures: $8^{\text {th }}$ production cycle. Journal of Food, Agriculture \& Environment, Helsinki, v. 11, n. 2, p. 1437-1443, 2013.

LITTELL, R. C.; MILLIKEN, G. A.; STROUP, W. W.; WOLFINGER, R. D.; SCHABENBERGER, O. SAS for mixed models. $2^{\text {th }}$ ed. Cary: SAS Institute, $2006.813 \mathrm{p}$.

MARTUSCELLO, J. A.; FONSECA, D. M.; NASCIMENTO JÚNIOR, D.; SANTOS, P. M.; RIBEIRO JÚNIOR, J. I.; CUNHA, D. N. F. V.; MOREIRA, L. M. Características morfogênicas e estruturais do capimXaraés submetido à adubação nitrogenada e desfolhação. Revista Brasileira Zootecnia, Viçosa, MG, v. 34, n. 5, p. 1475-1482, 2005.

MATOS, A. T.; SILVA, D. F.; LO MONACO, P. A. V.; PEREIRA, O. G. Produtividade e composição química do capim-tifton 85 submetido a diferentes taxas de aplicação do percolado de resíduo sólido urbano. Engenharia Agrícola, Jaboticabal, v. 33, n. 1, p. 188-200, 2013.

MEDEIROS, L. T.; REZENDE, A. V.; VIEIRA, P. F.; CUNHA NETO, F. R.; VALERIANO, A. R.; CASALI, A. O.; GASTALDELlO JUNIOR, A. L. Produção e qualidade da forragem de capim-marandu fertiirrigada com dejetos líquidos de suínos. Revista Brasileira de Zootecnia, Viçosa, MG, v. 36, n. 2, p. 309-318, 2007.

MONDARDO, D.; CASTAGNARA, D. D.; OLIVEIRA, P. S. R.; ZOZ, T.; MESQUITA, E. E. Produção e composição químico-bromatológica da aveia preta fertilizada com doses crescentes de dejeto líquido suíno. Revista Ciência Agronômica, Fortaleza, v. 42, n. 2, p. 509-517, 2011.
RIBEIRO, A. C.; GUIMARÃES, P. T. G.; ALVARES, V. H. Recomendações para o uso de corretivos $e$ fertilizantes em Minas Gerais. $5^{\text {a }}$ Aproximação. Viçosa, MG: Comissão de Fertilidade do Solo do Estado de Minas Gerais, CFSEMG, 1999. 359 p.

SANTOS JÚNIOR, J. D. G.; MONTEIRO, F. A.; LAVRES JUNIOR, J. Análise de crescimento do capimmarandu submetido a doses de nitrogênio. Revista Brasileira de Zootecnia, Viçosa, MG, v. 33, n. 6, p. 19851991, 2004. Suplemento 2.

SANTOS, M. E. R.; FONSECA, D. M.; BALBINO, E. M.; MONNERAT, J. P. I.; SILVA, S. P. Capimbraquiária diferido e adubado com nitrogênio:produção e características da forragem. Revista Brasileira de Zootecnia, Viçosa, MG, v. 38, n. 4, p. 650-656, 2009.

SARMENTO, P.; RODRIGUES, L. R. A.; LUGÃO, S. M. B.; CRUZ, M. C. P.; CAMPOS, F. P.; FERREIRA, M. E.; OLIVEIRA, R. F. Sistema radicular do Panicum maximum Jacq. cv. IPR-86 Milênio adubado com nitrogênio e submetido à lotação rotacionada. Revista Brasileira de Zootecnia, Viçosa, MG, v. 37, n. 1, p. $27-$ 34, 2008.

SCHEFFER-BASSO, S. M.; ELLWANGER, M. F.; SCHERER, C. V.; FONTANELI, R. S. Resposta de pastagens perenes à adubação com chorume suíno: cultivar Tifton 85. Revista Brasileira de Zootecnia, Viçosa, MG, v. 37, n. 11, p. 1940-1946, 2008.

SOLLENBERGER, L. E. Sustainable production systems for Cynodon species in the subtropics and tropics. Revista Brasileira de Zootecnia, Viçosa, MG, v. 37, p. 85-100, 2008. Número Especial.

VIELMO, H.; BONA FILHO, A.; SOARES, A. B.; ASSMANN, T. S.; ADAMI, P. F. Effect of fertilization with fluid swine slurry on production and nutritive value of Tifton 85. Revista Brasileira de Zootecnia, Viçosa, MG, v. 40, n. 1, p. 60-68, 2011. 
